\title{
Influence of environmental factors on zooplankton assemblages in Bosten Lake, a large oligosaline lake in arid northwestern China
}

\author{
Li-li Dai ${ }^{\mathrm{a}, \mathrm{b}}$, Ying-chun Gong ${ }^{\mathrm{a}}$, Xue-mei Li ${ }^{\mathrm{c}}$, Wei-song Feng ${ }^{\mathrm{a}}$, Yu-he Yu ${ }^{\mathrm{a}, *}$ \\ a Key Laboratory of Aquatic Biodiversity and Conservation of Chinese Academy of Sciences, \\ Institute of Hydrobiology, Chinese Academy of Sciences, Wuhan 430072, China \\ b Graduate University of the Chinese Academy of Sciences, Beijing 100039, China \\ c Yangtze River Fisheries Research Institute, Chinese Academy of Fishery Sciences, Wuhan 430223, China
}

*Corresponding author, e-mail: yhyu@ihb.ac.cn

Received 9 Jan 2013

Accepted 25 Jul 2013

\begin{abstract}
Water salinization in semi-arid and arid regions is threatening freshwater or oligosaline ecosystems. Anthropogenic processes enrich nutrients of aquatic systems causing significant environmental effects. Bosten Lake in Xinjiang Province, China is an interesting ecosystem featuring a salinity gradient from fresh to subsaline, as well as a nutrition gradient from oligotrophic to mesotrophic. In the present study, we focused on the effects of salinity and nutrients in Bosten Lake by investigating the zooplankton assemblages and environmental factors from different sampling times. A total of 74 zooplankton taxa were found, consisting of 34 rotifers, 26 protists, 10 cladocerans, and 4 copepods. Although no significant differences were found among different sampling sites, zooplankton species richness, diversity, and evenness showed significant differences between sampling times, with August samples showing highest values along with water temperature and total nitrogen. Principal component analysis and representational difference analysis results showed that zooplankton abundance is correlated with water temperature and nitrogen, but showed no significant relationship with water mineralization or conductivity. The subsaline-tolerating zooplankton species in Bosten Lake made their community insensitive to salinity. The decrease of total nitrogen concentration in Bosten Lake probably implied a primary productivity increase, which subsequently caused the zooplankton diversity to increase in August.
\end{abstract}

KEYWORDS: semiarid, salinization, nutrient enrichment, abundance, biomass, primary productivity

\section{INTRODUCTION}

Waters in semi-arid and arid regions (i.e., drylands with annual mean rainfall between 25 and $500 \mathrm{~mm}$ ) are threatened by rising salinities owing to natural, and more generically, anthropogenic processes ${ }^{1}$. Environmental impacts of salinization include decrease of species diversity and abundance ${ }^{2}$, change in the natural character of aquatic ecosystems, i.e., enhancement of clarification rate $^{3}$, change in the relative proportions of cations and anions ${ }^{4}$, anoxia of bottom water ${ }^{5}$, elevated levels of sulphate, dissolved iron and, nitrate $^{6}$, and reduction of water productivity ${ }^{7}$. The extent of impact of rising salinities in these waters depends upon both the range of increase in salinity and their original (natural) salinity. For the former, different salinity thresholds have even been defined along salinity gradients ${ }^{8}$. For example, the threshold salinity level functionally delimiting freshwater from brackish lake communities has been suggested to oc- cur at 2 psu (practical salinity units) ${ }^{9}$. And the greatest impacts may occur when original salinities are low ${ }^{1}$, for the more limited halotolerance of the freshwater biota than the biota of salt lakes. Hence freshwater or oligosaline ecosystems may be much more sensitive to salinity variations, and small increases may make big difference.

Another common impact of anthropogenic processes altering aquatic systems is nutrient enrichment ${ }^{10}$. It has been recognized since the 1970's that anthropogenic nutrient loading can lead to undesired algal blooms, fish death, and loss of zooplankton diversity ${ }^{11}$. Aquatic habitats also experience natural nutrient pulses during spring run-off turnover and rainstorms ${ }^{12}$. Thus nutrient pulses tend to be a major environmental factor influencing aquatic communities. Lakes that have different levels of primary productivity are characterized by different zooplankton assemblages ${ }^{13}$. Species composition is expected to change in response to increasing nutrient levels 
Table 1 Different areas in Bosten Lake and their characteristics.

\begin{tabular}{lll}
\hline Area & Location & \multicolumn{1}{c}{ Characteristics } \\
\hline I & Huangshuigou & $\begin{array}{l}\text { 69\% industry and agricultural wastewater are discharged into Bosten Lake through this area. The water is } \\
\text { extensive in recent lake sediments and serious in water organic contamination. } \\
\text { Located between Dahekou and Huangshuigou. The water is rich in aquatic vascular plants. } \\
\text { The only freshwater entering area in Bosten Lake. The water is rich in aquatic vascular plants, intense in water } \\
\text { exchange, high in sediment concentration, and low in salinity. }\end{array}$ \\
III & $\begin{array}{l}\text { Heishuiwan } \\
\text { Dahekou }\end{array}$ & $\begin{array}{l}\text { Average water quality. Rich in sediment concentration. Water is exchanged through wind and evaporation. } \\
\text { High in salinity, weak in water exchange and rich in aquatic vascular plants. Water is exchanged through wind } \\
\text { and evaporation. }\end{array}$ \\
\hline
\end{tabular}

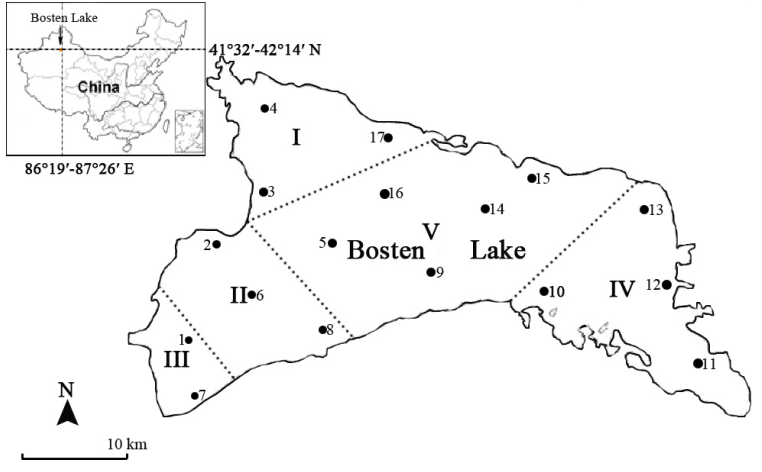

Fig. 1 Sampling sites in Bosten Lake: I Huangshuigou (3, 4, 17), II Heishuiwan $(2,6,8)$, III Dahekou $(1,7)$, IV Dacaohu $(10,11,12,13), \mathrm{V}$ the lake centre $(5,9,14,15,16)$.

and productivity ${ }^{13}$, and the diversity will also change when the initial system level was relatively low ${ }^{14}$. In naturally nutrient-poor habitats, increased nutrient inputs would be expected to produce an increase in species diversity - although experiments often show a reduction in diversity following experimental enrichment, possibly owing to dispersal limitation at the timescale over which the experiments are conducted ${ }^{15}$.

The Bosten Lake basin is located in the southern arid region of Xinjiang, China, and its main functions are water resources control, irrigation, and preservation of natural habitat ${ }^{16}$. Bosten Lake was the largest inland freshwater lake in China before the $1960 \mathrm{~s}$. In the past 50 years, however, owing to both natural and anthropogenic processes ${ }^{17}$, it has evolved from a freshwater to an oligosaline lake, and becomes a mesotrophic lake, sometimes, reaching the light eutrophic state ${ }^{18}$. Bosten Lake represents an interesting ecosystem featuring a complex hydrology and an intra-system salinity gradient, as well as a nutrition gradient from oligotrophic to mesotrophic ${ }^{19}$. In the present study, we focused on the saline and nutrient effect in Bosten Lake to compare zooplankton assemblage and environmental factors for different sampling times. The objectives of this study were
(1) to determine the zooplankton assemblage in this oligosaline lake; (2) to survey the environmental factors in Bosten Lake; and (3) to evaluate the influence of environmental factors on zooplankton communities.

\section{MATERIALS AND METHODS}

\section{Study sites}

Bosten Lake (E 86 $19^{\prime}-87^{\circ} 26^{\prime}$ and $\mathrm{N} 41^{\circ} 32^{\prime}$ $42^{\circ} 14^{\prime}$ ) is the largest lake in Xinjiang, China, covering an area of $998 \mathrm{~km}^{2}$. It has an average depth more than $8 \mathrm{~m}$, and gets deeper towards the east ${ }^{20}$. According to different characteristics between areas, Bosten Lake can be divided into 5 areas $^{21}$ (Table 1). In the present study, we selected 17 sites to represent its five different areas (Fig. 1).

\section{Environmental factors}

The samples were collected in June, August and October in 2010. At the stations, depth-integrated samples were collected. Samples for physicochemical analyses were preserved in cold and dark conditions. Water temperature $\left({ }^{\circ} \mathrm{C}\right)$, water depth $(\mathrm{m}), \mathrm{pH}$, dissolved oxygen (DO), water transparency, total dissolved solids (TDS), and conductivity were measured in situ using the YSI-6600-V2 Sonde water quality monitoring system (YSI Incorporated, USA). The concentration of the suspended matter $(\mathrm{mg} / \mathrm{l})$ was determined by measuring the dry weight of the residue after filtration through a Whatman GF/C membrane. Nutrients, including ammonium $\left(\mathrm{NH}_{4}-\mathrm{N}\right)$, nitrate $\left(\mathrm{NO}_{3}-\mathrm{N}\right)$, total nitrogen $(\mathrm{TN})$, orthophosphate $\left(\mathrm{PO}_{4}-\mathrm{P}\right)$ and total phosphorus (TP) concentrations were analysed by standard colorimetric techniques and were expressed as $\mathrm{mg} / \mathrm{l}$. Sub samples for quantification of chlorophyll $a$, were filtered using Whatman GF/C filters $(1.2 \mu \mathrm{m}$ pore size and $25 \mathrm{~mm}$-diameter) and pigment extraction was performed with $90 \%$ acetone $^{22}$. The concentrations were determined by the spectrophotometry based on the absorbance at 750 and $663 \mathrm{~nm}$. 
Table 2 Limnological characteristics of Bosten Lake.

\begin{tabular}{|c|c|c|c|c|c|c|c|c|c|c|c|c|c|c|c|}
\hline & \multicolumn{5}{|c|}{ June } & \multicolumn{5}{|c|}{ August } & \multicolumn{5}{|c|}{ October } \\
\hline & I & II & III & IV & $\mathrm{V}$ & I & II & III & IV & $\mathrm{V}$ & I & II & III & IV & $\mathrm{V}$ \\
\hline Water temp. $\left({ }^{\circ} \mathrm{C}\right)$ & 21.5 & 21.7 & 22.0 & 21.3 & 21.2 & 24.0 & 24.0 & 24.0 & 24.0 & 24.0 & 15.0 & 15.0 & 15.0 & 15.0 & 15.0 \\
\hline Water depth (m) & 3.1 & 5.5 & 10.8 & 3.8 & 6.6 & 3.6 & 5.5 & 10.7 & 4.8 & 7.3 & 3.2 & 5.0 & 8.9 & 4.6 & 6.7 \\
\hline Transparency $(\mathrm{cm})$ & 180.0 & 346.7 & 490.0 & 240.0 & 296.0 & 150.0 & 213.0 & 230.0 & 163.0 & 258.0 & 160.0 & 303.0 & 300.0 & 265.0 & 268.0 \\
\hline $\mathrm{pH}$ & 8.66 & 8.73 & 8.69 & 8.68 & 8.66 & 8.45 & 8.55 & 8.67 & 8.63 & 8.63 & 8.78 & 8.78 & 8.77 & 8.77 & 8.76 \\
\hline $\mathrm{DO}(\mathrm{mg} / \mathrm{l})$ & 6.3 & 7.0 & 6.7 & 6.6 & 6.7 & 7.2 & 6.9 & 7.6 & 7.6 & 7.4 & 7.4 & 7.1 & 6.8 & 6.9 & 7.0 \\
\hline $\mathrm{BOD}_{5}(\mathrm{mg} / \mathrm{l})$ & 1.7 & 1.6 & 1.7 & 1.9 & 1.7 & 1.9 & 2.0 & 1.8 & 2.0 & 2.1 & 0 & 0 & 0 & 0 & 0 \\
\hline $\mathrm{COD}(\mathrm{mg} / \mathrm{l})$ & 2.6 & 2.1 & 2.5 & 2.4 & 2.4 & 2.7 & 2.8 & 2.5 & 2.6 & 2.8 & 2.3 & 2.5 & 2.3 & 2.3 & 2.0 \\
\hline Permanganate value & 5.8 & 6.1 & 6.3 & 5.7 & 5.7 & 6.2 & 6.2 & 5.4 & 6.1 & 5.4 & 5.0 & 5.5 & 5.4 & 5.9 & 4.9 \\
\hline TDS (mg/l) & 1705 & 1577 & 1580 & 1477 & 1385 & 1475 & 1613 & 1450 & 1415 & 1370 & 1450 & 1497 & 1420 & 1518 & 1424 \\
\hline Conductivity $(\mu \mathrm{S} / \mathrm{cm})$ & 258 & 185 & 183 & 174 & 157 & 263 & 246 & 182 & 177 & 174 & 229 & 222 & 215 & 228 & 211 \\
\hline Chlorophyll $a(\mu \mathrm{g} / \mathrm{l})$ & 2.63 & 1.30 & 1.41 & 2.04 & 1.62 & 3.11 & 2.49 & 2.39 & 2.02 & 2.37 & 3.75 & 2.25 & 2.94 & 3.08 & 3.34 \\
\hline Nitrate $(\mathrm{mg} / \mathrm{l})$ & 0.38 & 0.39 & 0.40 & 0.38 & 0.42 & 0.25 & 0.27 & 0.24 & 0.24 & 0.29 & 0.28 & 0.26 & 0.28 & 0.28 & 0.30 \\
\hline $\mathrm{NH}_{4}-\mathrm{N}(\mathrm{mg} / \mathrm{l})$ & 0.14 & 0.13 & 0.13 & 0.15 & 0.13 & 0.17 & 0.17 & 0.17 & 0.19 & 0.18 & 0.34 & 0.29 & 0.19 & 0.26 & 0.21 \\
\hline $\mathrm{TN}(\mathrm{mg} / \mathrm{l})$ & 1.20 & 0.96 & 0.95 & 1.00 & 0.98 & 0.82 & 0.91 & 0.86 & 0.88 & 0.81 & 1.02 & 1.03 & 1.04 & 0.98 & 0.96 \\
\hline $\mathrm{TP}(\mathrm{mg} / \mathrm{l})$ & 0.005 & 0.013 & 0.003 & 0.026 & 0.026 & 0.003 & 0.007 & 0.002 & 0.007 & 0.012 & 0 & 0 & 0 & 0 & 0 \\
\hline Fluoride (mg/l) & 0.529 & 0.516 & 0.482 & 0.462 & 0.439 & 0.486 & 0.579 & 0.533 & 0.476 & 0.433 & 0.550 & 0.530 & 0.497 & 0.541 & 0.499 \\
\hline Chloride (mg/l) & 211.5 & 196.7 & 191.7 & 181.8 & 167.1 & 310.0 & 343.0 & 301.0 & 294.0 & 287.0 & 441.0 & 443.0 & 407.0 & 454.0 & 405.0 \\
\hline Sulphate $(\mathrm{mg} / \mathrm{l})$ & 364 & 333 & 324 & 310 & 285 & 545 & 596 & 516 & 507 & 496 & 688 & 691 & 638 & 710 & 636 \\
\hline
\end{tabular}

* Characteristics were shown as average values for Huangshuigou (I), Heishuiwan (II), Dahekou (III), Dacaohu (IV), and the lake centre $(\mathrm{V})$.

\section{Zooplankton}

Zooplankton sampling procedures were conducted in parallel to physicochemical analyses with our typical lab method ${ }^{23}$. Samples for qualitative analysis were collected by filtering pooled water through a No. 25 plankton net. Samples for quantitative analysis were fixed in $4 \%$ formalin, settled for $24 \mathrm{~h}$, and finally concentrated to $30 \mathrm{ml}$. Zooplankton identification was performed under an Axioplan 2 imaging microscope (Zeiss, Jena, Germany). Zooplankton was presented in terms of abundance (ind/l) and biomass ( $\mu \mathrm{g} / \mathrm{l})$. The level of community structure was assessed according to the diversity index $\left(H^{\prime}\right)^{24}$, Simpson index $(D)^{25}$, and Pielou's evenness index $\left(J^{\prime}\right)^{26}$. These indexes were calculated from the annual average density of zooplankton:

$$
H^{\prime}=-\sum_{i=1}^{S} \frac{n_{i}}{n} \log _{2}\left(\frac{n_{i}}{n}\right),
$$

where $n_{i}$ is the average density of the $i$ th species, $n$ is the average density of the entire community, and $S$ is the total number of species.

$$
1-D=\sum\left(N_{i} / N\right)^{2}
$$

where $N_{i}$ is the density of the $i$ th species and $N$ is the number of species.

$$
J^{\prime}=\frac{H^{\prime}}{\ln S} .
$$

\section{Statistical analysis}

Statistical significance between samples was determined by LSD (least significant difference) $t$ test and SNK (Student-Newman-Keuls) $q$ test performed using SPSS 16.0 for Windows. It was also used to compare physicochemical variables between all the stations and between the seasons. The species composition (0/1) matrix was used to perform the unweighted pair-group method using arithmetic averages (UPGMA) clustering with XLSTAT-Pro 2006 (Addinsoft, NY, USA). The relationships between zooplankton assemblages and environmental variable features were explored by principal component analysis (PCA) ordination using CANOCO 4.5 and representational difference analysis (RDA) following Ref. 27.

\section{RESULTS}

\section{Environmental parameters}

Physicochemical characterization of Bosten Lake was summarized in Table 2. The total dissolved solids reached a high level of $2020 \mathrm{mg} / \mathrm{l}$ in June, and the water conductivity could reach up to $372 \mu \mathrm{S} / \mathrm{cm}$ in August, indicating a slight salinization in this lake. Sulphate and chloride were the main ions in this lake, constituting $34 \%$ and $21 \%$ of the total dissolved solids, respectively. From the nutrient analysis of Bosten Lake, the concentration of total phosphorus was low, especially in October when it was below the detection limit (marked $0 \mathrm{mg} / \mathrm{l}$ ). The concentration of total nitrogen reached its highest value in June $(1.45 \mathrm{mg} / \mathrm{l})$. 
Water depths were ranged from greater than $10 \mathrm{~m}$ in the central site to approximately $1 \mathrm{~m}$ at the shallowest site of western Bosten Lake. Different sampling sites displayed roughly the same transparencies corresponding to no significant differences of physicochemical parameters $(p>0.05)$. The difference in the chlorophyll $a$ concentrations between the sampling sites was also negligible $(p>0.05)$.

A significant variation of water temperature was observed between different sampling times (ANOVA, $F=588$, d.f. $=50, p<0.001)$, ranging from $11.8^{\circ} \mathrm{C}$ in October to $24^{\circ} \mathrm{C}$ in August (Table 2). Dissolved oxygen also changed significantly, from lowest in June to highest in August. Ammonium nitrogen concentrations reached the highest values in October and dropped to the lowest values in June. $\mathrm{pH}$ values were significantly higher in October. However, the concentrations of nitrate and chlorophyll $a$ were significantly lower in June. Furthermore, the total nitrogen concentrations in August were significantly lower. The mineralization and conductivity values from sampling times were significantly different (Kruskal Wallis test: d.f. $=2, p<0.05, p<0.01$, respectively).

\section{Zooplankton assemblage}

A total of 74 zooplankton species were found in Bosten Lake, consisting of 34 rotifer, 26 protist, 10 cladoceran, and 4 copepod species (Table 3). Most of them were widespread species, while many uncommon species, discovered mostly between submerged vegetation, were also found, e.g., Cephalodella sp., Dissotrocha aculeata, Lecane leontina, L. ohioensis, Monostyla furcata, M. ornate, Mytilina ventralis, and Schizocerca diversicornis. In addition, a brackish or marine water species-Brachionus plicatilis — was detected in our analysis.

Species were also varied with sampling times. Bosmina longirostris and Microcyclops sp. were common species in all samples. Ceriodaphnia quadrangula, Ciliate sp., Daphnia hyalina, Diaphanosoma leuchtenbergianum, Halteria grandinella, Harpacticoida sp., Keratella cochlearis, Polyphemus pediculus and Strobilidium gyrans were common species in June samples. Brachionus angularis, Ceriodaphnia quadrangula, Collotheca sp., Euglypha sp., Filinia longiseta, K. cochlearis, Pedalia mira, Polyarthra trigla and Trichocerca pusilla were common August species. While Ciliate sp., Daphnia hyalina, Diaphanosoma leuchtenbergianum, Halteria grandinella, Tintinnidium fluviatile and Vorticella sp. were common species found in October.

Zooplankton abundance in Bosten Lake were ranged from $0-810 \mathrm{ind} / \mathrm{l}$ and the average abundance
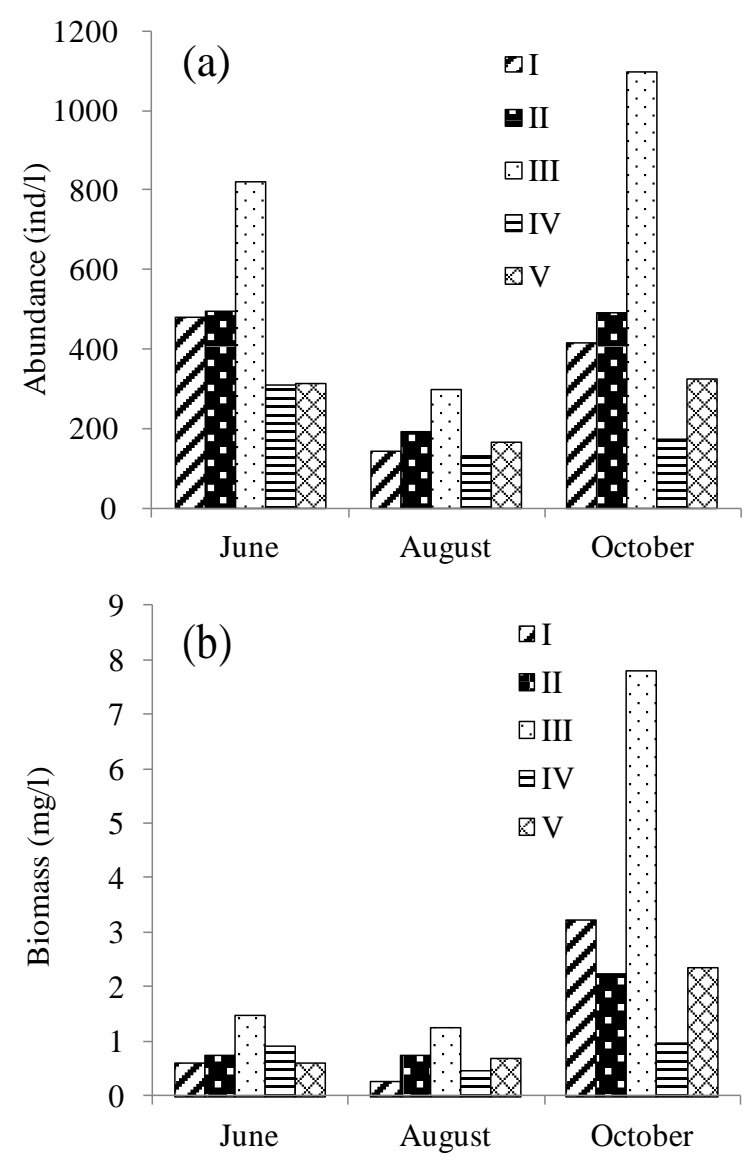

Fig. 2 Zooplankton total abundance and biomass at different sampling times: (a) total abundance and (b) biomass. I indicates samples in Huangshuigou, II in Heishuiwan, III in Dahekou, IV in Dacaohu, and V in the lake centre.

was low, only 6 ind/l. The total zooplankton abundance in June samples was 7692 ind/l, with protozoa, nauplius, copepods, cladocerans, and rotifers constituting $70 \%, 14 \%, 9 \%, 4 \%$, and $4 \%$, respectively. In August samples, however, rotifers took the major part of zooplankton abundance (3065 ind/l), reaching 60\%, and followed by nauplius (14\%), cladocerans (12\%), protozoa $(10 \%)$, and copepods $(4 \%)$. In October samples protozoa took the major part of zooplankton abundance of $7403 \mathrm{ind} / \mathrm{l}$, reaching $65 \%$, followed by cladocerans (34\%) and rotifers (1\%). Copepods and nauplius were rare samples in October. The zooplankton biomass in Bosten Lake were ranged from 0.27$7.80 \mathrm{mg} / \mathrm{l}$ with the average of $0.87,0.68,3.32 \mathrm{mg} / \mathrm{l}$ in June, August and October, respectively.

The protozoan species abundance was much higher than other zooplankton species in Bosten Lake, with Strobilidium gyrans reaching 194 ind/l in Octo- 
Table 3 List of zooplankton species present in different sampling times.

\begin{tabular}{|c|c|c|c|c|c|c|c|c|c|c|c|c|c|c|c|}
\hline & \multicolumn{5}{|c|}{ June } & \multicolumn{5}{|c|}{ August } & \multicolumn{5}{|c|}{ October } \\
\hline & I & II & III & IV & $\mathrm{V}$ & I & II & III & IV & $\mathrm{V}$ & I & II & III & IV & $\mathrm{V}$ \\
\hline Protozoa & & & & & & & & & & & & & & & \\
\hline Actinophrys sol Ehrenberg & & & & & + & & & & & & & & & & \\
\hline Arcella vulgaris Ehrenberg & + & & & & & & & & & + & & & & & \\
\hline Askenasia volvox Eichwald & & & ++ & & & & & & & & + & & & & \\
\hline Centropyxis aculeate Ehrenberg & & & + & & & & & + & & & & & & & \\
\hline Centropyxis ecornis Ehrenberg & & & & & + & & & & & & & & & & \\
\hline Centropyxis platystoma Penard & + & & & ++ & & + & & + & & & & & & & \\
\hline Ciliate sp. & + & + & + & + & + & + & ++ & ++ & + & & + & + & +++ & ++ & +++++ \\
\hline Coleps hirtus Nitzsch & & + & + & ++ & & & & & & & & & & & \\
\hline Cyclidium glaucoma Müller & & & & & & & & & & & & & & +++ & \\
\hline Cyphoderia ampulla Müller & & & & & & & & + & & & & & & & \\
\hline Cyrtolophosis sp. & & & & & & & & & + & & & & & & \\
\hline Difflugia globulosa Dujardin & & & & & & & & ++ & & ++ & + & & + & & \\
\hline Difflugia oblonga Ehrenberg & & & & & & + & +++ & + & ++ & & & + & + & + & \\
\hline Euglypha sp. & & & & & & + & + & + & ++ & +++ & & 年 & & I & \\
\hline Euplotes sp. & & & & & & & & & & & & & & + & + \\
\hline $\begin{array}{l}\text { Halteria grandinella Müller } \\
\text { Hemiophrys sp. }\end{array}$ & ++ & + & ++ & $\begin{array}{c}+++ \\
+\end{array}$ & +++ & & & & & + & + & ++ & +++ & ++++ & ++++ \\
\hline Histriculus similis Quennerstedt & & + & + & & & & & & & & & & & & \\
\hline Lacrymaria sp. & & & & & & & & & + & & & & & & \\
\hline Prorodon sp. & & & & & & & + & + & & & & & & & \\
\hline Strobilidium gyrans Stokes & + & ++ & +++ & + & ++ & & & & & & & & & +++ & + \\
\hline Tintinnidium fluviatile Stein & & & & & & & & + & & + & + & + & ++ & + & ++ \\
\hline Tintinnopsis wangi $\mathrm{Nie}$ & & + & & & & & & & & & & & + & ++ & + \\
\hline Trachelophyllum sp. & & & & & & & & & & & + & & & ++ & + \\
\hline Urosoma sp. & & & & & & & + & + & & & & & & & +++ \\
\hline Vorticella sp. & + & + & & & & & & & & & ++ & + & ++ & + & +++ \\
\hline Rotifer & & & & & & & & & & & & & & & \\
\hline $\begin{array}{l}\text { Anuraeopsis fissa Gosse } \\
\text { Ascomorpha saltans } \text { Bartsch }\end{array}$ & + & + & & + & + & & + & ++ & + & $\begin{array}{l}+++ \\
+++\end{array}$ & + & & ++ & & ++ \\
\hline Asplanchna priodonta Gosse & + & & + & & & + & & ++ & + & + & & & & + & + \\
\hline Bdelloidea sp. ${ }^{*}$ & + & + & & + & & & ++ & & ++ & + & & & & & \\
\hline Brachionus angularis Gosse & + & + & & ++ & & + & ++ & +++ & ++ & +++ & & & & & \\
\hline Brachionus calyciflorus Pallas & & & & & & & & & + & + & & & & & \\
\hline Brachionus plicatilis Müller & & & & & & & & + & & + & & & & & \\
\hline Brachionus quadridentatus Hermann & & & & + & & & & & + & & & & & & \\
\hline $\begin{array}{l}\text { Brachionus urceolaris Müller } \\
\text { Cephalodella } \mathrm{sp} \text {. }\end{array}$ & + & ++ & & +++ & ++++ & & +++ & +++ & $\begin{array}{c}++++ \\
+\end{array}$ & $\begin{array}{c}+++++ \\
+\end{array}$ & + & & + & & \\
\hline Collotheca sp. & & & & ++ & + & ++ & +++ & +++ & ++++ & +++++ & & & ++ & & \\
\hline Dissotrocha aculeata Ehrenberg & & & & ++ & + & & + & & + & & & + & & + & \\
\hline Euchlanis dilatata Ehrenberg & & & & & & & & & + & + & & & & & \\
\hline F. longiseta Ehrenberg & & & & + & & ++ & +++ & +++ & ++++ & ++++ & & ++ & ++ & & \\
\hline K. cochlearis Gosse & ++ & + & +++ & ++ & +++ & + & + & +++ & +++ & ++ & + & & +++ & & + \\
\hline K. quadrata Müller & ++ & ++ & & ++++ & +++ & & & & + & + & & + & & & \\
\hline K. valga Ehrenberg & & + & & & + & ++ & ++ & +++ & & +++ & & & & & \\
\hline Lecane leontina Turner & & & & & & & & & + & & & & & & \\
\hline Lecane luna Müller & & & + & ++ & & + & & & & & & & & & \\
\hline Lecane ohiensis Herrick & & & & & & & & & + & & & & & & \\
\hline Lepadella ehrenbergii Perty & & & & & & & & + & & & & & & & \\
\hline Monostyla bulla Gosse & & & & & & + & & & +++ & + & & & & & \\
\hline Monostyla furcata Murray & & & & & & & & & & + & & & + & & + \\
\hline Monostyla lunaris Ehrenberg & & & & & & & & & & + & & & & & \\
\hline Monostyla ornata Harring \& Myers & & & & & & & & & & + & & & & & \\
\hline Monostyla pyriformis Daday & & & & & + & & & & & & & & & & \\
\hline Mytilina ventralis Ehrenberg & & & & & & & & & & + & & & & & \\
\hline Pedalia mira Hudson & & + & & & & ++ & +++ & +++ & +++ & +++++ & + & & & & \\
\hline Polyarthra trigla Ehrenberg & + & & & + & & ++ & +++ & +++ & ++++ & +++++ & & & ++ & & + \\
\hline Rotifer sp. & & & & + & & + & ++ & + & & + & & & + & & \\
\hline Schizocerca diversicornis Daday & & & & & & & & & & + & & & & & \\
\hline Testudinella patina Hermann & & & & ++ & & & & & & & & & & & \\
\hline Trichocerca pusilla Jennings & & + & & & & + & + & +++ & ++ & ++++ & & & + & & \\
\hline Trichotria tetractis Ehrenberg & & & & & + & & & & + & & & & & & \\
\hline Cladocera & & & & & & & & & & & & & & & \\
\hline Alona costata Sars & + & & & & & & & & & & & & & + & \\
\hline Alona quadrangularis Müller & + & & & & & & + & & & + & & + & + & + & \\
\hline Bosmina longirostris Müller & ++ & ++ & + & ++++ & ++ & ++ & + & +++ & ++++ & +++++ & ++ & ++ & +++ & ++++ & +++++ \\
\hline Ceriodaphnia quadrangula Müller & ++ & +++ & ++ & ++ & ++++ & + & + & ++ & ++ & +++ & + & + & + & & \\
\hline Chydorus ovalis Kurz & + & + & ++ & +++ & & & & & + & + & & + & + & ++ & \\
\hline Daphnia hyalina Leydig & ++ & ++ & +++ & ++ & +++ & & ++ & ++ & ++ & +++ & ++ & + & +++ & ++++ & +++++ \\
\hline $\begin{array}{l}\text { Diaphanosoma leuchtenbergianum } \\
\text { Graptoleberis testudinaria Fischer }\end{array}$ & + & + & +++ & +++ & ++ & & ++ & +++ & ++++ & ++++ & + & + & $\begin{array}{c}+++ \\
+\end{array}$ & ++ & ++++ \\
\hline Leptodora kindti Focke & + & + & + & & & & & + & & & & + & & ++ & + \\
\hline Polyphemus pediculus Linnaèus & + & ++ & ++ & + & ++++ & + & & + & & & + & & & & + \\
\hline 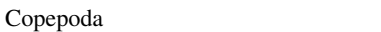 & & & & & & & & & & & & & & & \\
\hline Eucyclops macruroides Lilljeborg & & & + & & + & & & & & & & & & & \\
\hline Harpacticoida sp." & + & + & + & ++ & + & + & & & & + & & & & & \\
\hline Macrocyclops sp. & & + & & ++ & ++ & & & & + & & & & + & + & ++ \\
\hline Microcyclops sp. & ++ & +++ & +++ & ++++ & +++++ & +++ & +++ & +++ & +++++ & ++++++ & + & + & +++ & ++++ & ++++ \\
\hline
\end{tabular}

The number of ' + ' indicates frequency of species occurrences.

* Species of Ciliate, Bdelloidea rotifer, and Harpacticoida. 


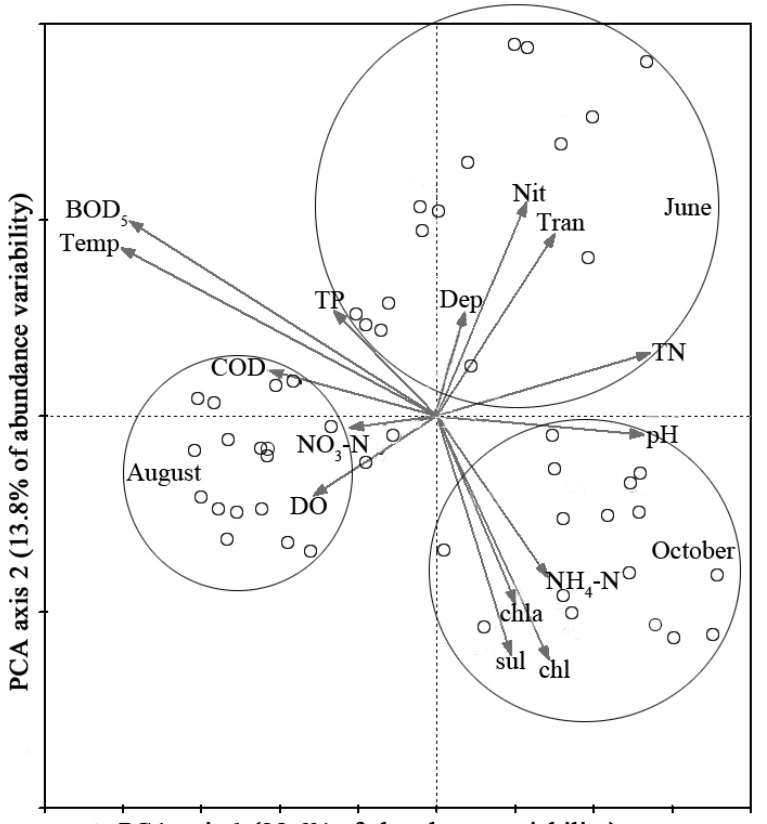

PCA axis 1 (28.6\% of abundance variability)

Fig. 3 Principal component analysis (PCA) of the first two axes on the zooplankton abundance data set. (DO): dissolved oxygen, (temp): water temperature, $\left(\mathrm{NO}_{3}-\mathrm{N}\right)$ : nitrate, (chla): chlorophyll $a$, (TN): total nitrogen, (TP): total phosphorus, $\left(\mathrm{NH}_{4}-\mathrm{N}\right)$ : ammonium, (Sus): suspended matter, (Tran): water transparency, (chl): chloride, (Sul): sulphate, (Per): permanganate value, (Dep): water depth. Cycles represents samples in different seasons.

ber samples. The total zooplankton species abundance in June samples was almost the same as in October samples (Fig. 2a). However, for the increase of crustacean abundance, the biomass reached highest in October samples (Fig. 2b).

The Shannon-Wiener diversity index in Bosten Lake was ranged from 1.11 in October to 2.36 in August. Similarly, the highest Simpson diversity index was detected in August, reaching 0.87. Pielou's evenness index also reached the highest of 0.83 in August and the lowest of 0.54. Through multiple comparisons, the species richness, diversity and evenness in August were significantly higher than in other sampling times (one-way ANOVA, d.f. $=50, p<$ $0.05, F=11.2,13.6,14.7$, respectively), while no differences were found between different sampling sites.

\section{Environment-zooplankton relationships}

PCA axes 1 and 2 represent $42 \%$ of the total variation in zooplankton community structure. Axis 1, representing the major axis of variation $(29 \%)$, was posi-
Table 4 Variance (var.) explained by each environmental variable, tested by RDA method.

\begin{tabular}{lccc}
\hline Variable & Explained var. (\%) & Significance & $\mathrm{FW}^{\mathrm{b}}$ \\
\hline Temperature & 21.5 & $0.01^{* *}$ & $\mathrm{X}$ \\
BOD $_{5}$ & 21.1 & $0.01^{* *}$ & \\
$\mathrm{TN}$ & 9.7 & $0.01^{* *}$ & \\
$\mathrm{pH}$ & 8.9 & $0.01^{* *}$ & \\
Chloride & 8.5 & $0.01^{* *}$ & \\
Transparency & 7.3 & $0.01^{* *}$ & $\mathrm{X}$ \\
Sulphate & 7.2 & $0.01^{* *}$ & \\
Nitrate & 6.9 & $0.01^{* *}$ & $\mathrm{X}$ \\
COD & 6.7 & $0.01^{* *}$ & \\
NH & & \\
Chla & 6.3 & $0.01^{* *}$ & \\
TP & 5.7 & $0.01^{* *}$ & \\
Permanganate val. & 4.8 & $0.05^{*}$ & \\
DO & 4.5 & $0.05^{*}$ & \\
Depth & 4.2 & $0.05^{*}$ & \\
\hline
\end{tabular}

${ }^{\mathrm{a}, \mathrm{b}}$ Unit, $P$ value; $\mathrm{FW}$, forward selection.

${ }^{*} p \leqslant 0.05 ;{ }^{* *} p \leqslant 0.01 ; \mathrm{X}$, selected by forward selection.

tively correlated with $\mathrm{pH}$ and total nitrogen (Fig. 3). Axis 1 was negatively correlated with water temperature, $\mathrm{BOD}_{5}, \mathrm{COD}$, and dissolved oxygen. PCA axis 2 was positively correlated with nitrate concentration, water transparency and permanganate values. The second PCA axis was negatively correlated with concentration of ammonium nitrogen, chlorophyll $a$, chlorides, and sulphates.

According to RDA results, zooplankton community variation showed a significant association with water temperature, $\mathrm{BOD}_{5}$, total nitrogen, and $\mathrm{pH}$ (Table 4). Suspended matter, degree of mineralization and conductivity of the water were not related to zooplankton communities. Results of the RDA for the main affecting factors on different zooplankton species are shown in Fig. 4. Temperature, nitrate and transparency could explain $31 \%$ of zooplankton abundance variability. Different species were evenly distributed along the axes, indicating a relatively high heterogeneity in Bosten Lake. Nauplius was closely related to water temperature, while Bosmina longirostris and Strobilidium gyrans were negatively correlated to water temperature. Halteria grandinella and Microcyclops sp. were significantly correlated to nitrate concentration.

\section{DISCUSSION}

Our study in Bosten Lake was carried out in the warm seasons, covering water temperatures from $11.8-24^{\circ} \mathrm{C}$. As a result, some zooplankton species preferring cold water could not be detected in our 


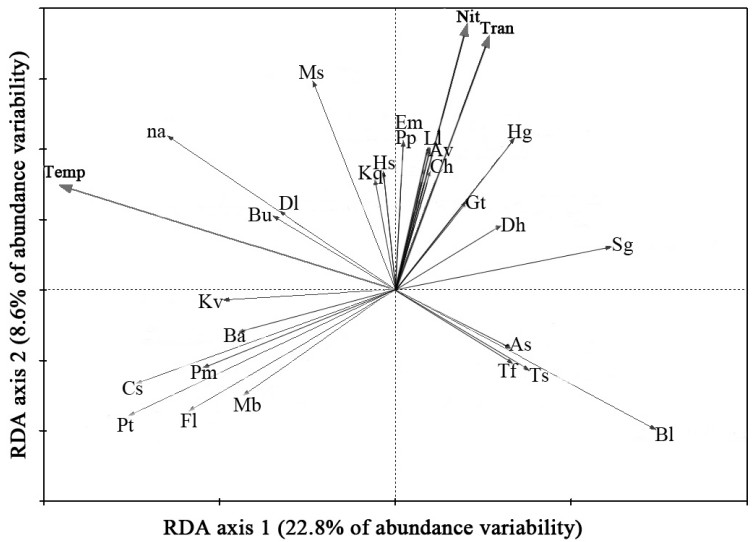

Fig. 4 Redundancy analysis (RDA) biplots of environmental factors and zooplankton abundance. The factors with major effect are depicted as solid arrows, others as thin arrows (only the significantly correlated species are depicted). As, Actinophrys sol; Av, Askenasia volvox; Ba, Brachionus angularis; $\mathrm{Bl}$, Bosmina longirostris; $\mathrm{Bu}$, Brachionus urceolaris; Ch, Coleps hirtus; Cs, Collotheca sp.; Dh, Daphnia hyalina; Dl, Diaphanosoma leuchtenbergianum; Em, Eucyclops macruroides; Fl, F. longiseta; Gt, Graptoleberis testudinaria; $\mathrm{Hg}$, Halteria grandinella; $\mathrm{Hs}$, Harpacticoida sp.; Kq, K. quadrata; Kv, K. valga; Ll, Lecane luna; Mb, Monostyla bulla; Ms, Microcyclops sp.; na, nauplius; Pm, Pedalia mira; Pp, Polyphemus pediculus; Pt, Polyarthra trigla; Sg, Strobilidium gyrans; Tf, Tintinnidium fluviatile; Ts, Trachelophyllum sp.

analysis. By comparing with previous zooplankton studies ${ }^{20,28,29}$, however, we found mainly Acanthodiaptomus and Daphinia cucullata developed in cold water in Bosten Lake, and a zooplankton abundance and richness peak appeared in May to November. Thus most of the zooplankton members in Bosten Lake were part of our analysis.

As a large lake in an arid region, Bosten Lake has rich characteristics, embodied in the existence of many uncommon species not detected in other places, such as Dissotrocha aculeata, Lecane leontina, L. ohioensis, Monostyla furcata, M. ornata, and Schizocerca diversicornis, which may due to the abundant of water grasses in Bosten Lake ${ }^{20}$. Meanwhile, owing to the oligosalination (the average salinity detected was $1490 \mathrm{mg} / \mathrm{l}$ ) in this lake, the zooplankton species diversity and abundance in Bosten Lake were low (with the averaged ShannonWiener index and abundance of 1.58 and $388 \mathrm{ind} / \mathrm{l}$, respectively), comparing to reservoirs or even rivers in Xinjiang ${ }^{30-32}$. However, although five different areas could be divided in this lake (Table 1), zooplankton assemblage (e.g., species diversity, abundance, and evenness) did not vary among different sampling sites, corresponding to no significant differences of environmental factors (e.g., physicochemical parameters and chlorophyll $a$ concentration).

By comparing zooplankton assemblage with environmental factors, we found zooplankton community varied significantly as physicochemical parameters changed between different sampling times. From June to October, dominant species varied (protozoan species in June and October, rotifers in August). Species diversity was highest in August, and cladocerans also developed in October (Fig. 2). These variations were correlated to environmental factors. Water temperature and dissolved oxygen reached highest values in August (with the average of $24^{\circ} \mathrm{C}$ and $7.3 \mathrm{mg} / \mathrm{l}$, respectively), which could cause the zooplankton peak. The pressure release of fish predator may allow cladocerans to improve in October ${ }^{20}$. We also found $\mathrm{pH}$ was positively correlated with zooplankton abundance, indicating that the higher $\mathrm{pH}$ in October may contribute to the cladoceran increase.

Salinity has long been considered an important influence on the composition and dynamics of aquatic ecosystems ${ }^{33}$, and species richness of microfauna was generally negatively correlated with salinity levels in lakes ${ }^{34}$. Nielsen et al ${ }^{35}$ found zooplankton species richness and abundance reduced at salinities between 1000 and $5000 \mathrm{mg} / \mathrm{l}$. The average salinity was $1474 \mathrm{mg} / \mathrm{l}$ in Bosten Lake during our study, which meant a probable effect of saline on zooplankton community in this lake. Considering no zooplankton research had been conducted before the lake became saline, we compared variations of zooplankton communities together with water mineralization and conductivity. Although both mineralization and conductivity changed significantly during the sampling times, they were not significantly correlated with the first two main PCA axes (Fig. 3). Furthermore, they were not related to zooplankton communities according to the RDA results (Table 4). This may due to the zooplankton community adaptability in this oligosaline lake, with only subsaline tolerant members remaining.

The effects of even small rises in the salinity of fresh waters can be profound because the halotolerance of the freshwater biota is more limited than the biota of salt lakes ${ }^{1}$. The zooplankton in Bosten Lake, however, probably have established a community tolerant to slight salinization variations during the past 50 years. In the present study, most of the detected zooplankton taxa were freshwater species. Nevertheless, many of them have also been detected in saline lakes, for example, 
Table 5 Dominant species found in Bosten Lake and examples of their existence in saline environment of previous records. Note that this table does not provide an exhaustive record of what can be found in the published literature.

\begin{tabular}{llc}
\hline Dominant species & $\begin{array}{l}\text { Environment of } \\
\text { the study site }\end{array}$ & References \\
\hline Actinophrys sol & saline water & present study \\
Anuraeopsis fissa & saline water & 39 \\
Bosmina longirostris & saline water & 40 \\
Brachionus urceolaris & saline lake & 37 \\
Coleps hirtus & brackish water & 41 \\
Collotheca sp. & saline water & present study \\
Cyphoderia ampulla & salt mash & 42 \\
Daphnia hyalina & saline water & 43 \\
Diaphanosoma & saline lake & 44 \\
leuchtenbergianum & & \\
Difflugia oblonga & salt mash & 42 \\
Euglypha sp. & saline water & present study \\
Euplotes sp. & saline water & present study \\
F. longiseta & saline lake & 37 \\
Halteria grandinella & saline lake & 45 \\
K. cochlearis & subsaline lake & 36 \\
K. quadrata & costal lake & 2 \\
Strobilidium gyrans & saline-alkaline pond & 46 \\
Microcyclops sp. & saline water & present study \\
Monostyla furcata & saline water & present study \\
Pedalia mira & saline water & present study \\
Polyarthra trigla & saline water & 40 \\
\hline & &
\end{tabular}

Anuraeopsis fissa, Brachionus angularis, Brachionus calyciflorus, Brachionus quadridentatus, Brachionus urceolaris, Brachionus plicatilis, Euchlanis dilatata, F. longiseta, K. cochlearis, Lecane luna, Lepadella patella, Mytilina ventralis, Platyias quadricornis, Testudinella patina (the salinity could reach up to $10 \mathrm{~g} / \mathrm{l})^{36,37}$, which means that many zooplankton taxa in Bosten Lake have a good adaptability to salinization. Furthermore, the negative relationship between microfauna community and salinity levels in lakes may be driven by one particularly diverse or dominant taxonomic group which constitutes a significant proportion of the species in a system ${ }^{38}$. However, most of the dominant species in our study were euryhaline (Table 5), which may consequently determine the subsaline accustomed community in Bosten Lake.

According to RDA results (Table 4), we also found total nitrogen concentration significantly contributed to zooplankton variability in addition to water temperature. In the present study, we detected the lowest total nitrogen concentration in August samples, which may be due to the phytophankton's high reproduction in August in Bosten Lake ${ }^{47}$. Meanwhile, we observed the highest zooplankton diversity in August samples, although their abundances were the lowest. Hence we deduce the increase of nitrogen concentration in Bosten Lake could raise the zooplankton diversity. Empirical evidence suggests that species richness often exhibits a unimodal ("hump-shaped") pattern with increasing primary productivity ${ }^{48}$. Lacustrine species richness is influenced by lake productivity. Pure water in rock pools supports few or no species ${ }^{49}$ and the most productive lakes, such as sewage lagoons, also show low species richness ${ }^{50}$. Lakes between these extremes of primary productivity generally have the highest species richness, at least for crustacean zooplankton ${ }^{51}$. The productivity of Bosten Lake was probably below the peak value of its unimodal curve. Thus with the concentration of total nitrogen getting down in August, the primary productivity of Bosten Lake increased, which led to the increase of zooplankton diversity. It is worth mentioning that this increase originate from the macrophyte, as no difference of chlorophyll $a$ concentration was found between August and October samples, while dissolved oxygen reached highest in August samples. However, a more intensive analysis on both macrophyte and zooplankton community is needed to fully understand nutrient effects on zooplankton in Bosten Lake.

Acknowledgements: The authors thank Dr Henri Gerken in Arizona State University for his review of the manuscript and suggestion to improve the English. This work was supported by the National Natural Science Foundation of China Grant Nos. 30900130 and 31011120092 to Y. C. Gong.

\section{REFERENCES}

1. Williams WD (1999) Salinisation: A major threat to water resources in the arid and semi-arid regions of the world. Lakes Reservoirs 4, 85-91.

2. Schallenberg M, Hall CJ, Burns CW (2003) Consequences of climate-induced salinity increases on zooplankton abundance and diversity in coastal lakes. Mar Ecol Progr 251, 181-9.

3. Grace MR, Hislop TM, Hart BT, Beckett R (1997) Effects of saline groundwater on the aggregation and settling of suspended particles in a turbid Australian river. Colloid Surface A 120, 123-41.

4. Radke L, Howard KWF, Gell PA (2002) Chemical diversity in south-eastern Australian saline lakes. I. Geochemical causes. Mar Freshwat Res 53, 941-59.

5. Ryan T, Gasior R, Steegstra D (1999) Habitat degradation associated with saline stratification. Report produced for the Murray-Darling Basin Commission, Natural Resource Management Strategy - Project V238. Anthur Rylah Institute for Environmental Research, Melbourne. 
6. Hines ME, Lyons WB, Lent RM, Long DT (1992) Sedimentary biogeochemistry of an acidic, saline groundwater discharge zone in Lake Tyrrell, Victoria, Australia. Chem Geol 96, 53-65.

7. Evans MS, Arts MT, Robarts RD (1996) Algal productivity, algal biomass, and zooplankton biomass in a phosphorus-rich, saline lake: deviations from regression model predictions. Can J Fish Aquat Sci 53, 1048-60.

8. Remane A, Schlieper C (1971) The Biology of Brackish Waters, 2nd edn, Wiley Interscience, New York.

9. Jeppesen E, Søndergaard M, Kanstrup E, Petersen B, Eriksen RB, Hammershøj M, Mortensen E, Jensen JP, Have A (1994) Does the impact of nutrients on the biological structure and function of brackish and freshwater lakes differ? Hydrobiologia 275-6, 15-30.

10. Carpenter SR, Caraco NF, Correll DL, Howarth RW, Sharpley AN, Smith VH (1998) Non-point pollution of surface waters with phosphorus and nitrogen. Ecol Appl 8, 559-68.

11. Schindler DW (1974) Eutrophication and recovery in experimental lakes: implications for lake management. Science 184, 897-9.

12. Meyer JL, Likens GE (1979) Transport and transformation of phosphorus in a forest stream ecosystem. Ecology 60, 1255-69.

13. Leibold MA, Chase JM, Shurin JB, Downing AL (1997) Species turnover and the regulation of trophic structure. Annu Rev Ecol Systemat 28, 467-94.

14. Dodson SI, Arnott SE, Cottingham KL (2000) The relationship in lake communities between primary productivity and species richness. Ecology 81, 2662-79.

15. Cottingham KL, Carpenter SR (1998) Population, community and ecosystem variates as ecological indicators: phytoplankton responses to whole-lake enrichment. Ecol Appl 8, 508-30.

16. Xia J, Zuo QT, Pang JW (2001) Enlightenment on sustainable management of water resources from past practices in the Bositeng Lake basin, Xinjiang, China. In: Regional Management of Water Resources. IAHS Publ. no. 268, pp 41-8.

17. Zhou CH, Luo GP, Li P, Li C, Tang QC (2001) Enviromental change in Bosten Lake and its relation with the oasis reclamation in Yanqi Basin. Geogr Res 20, 14-23.

18. Xie GJ, Zhang JP, Tang XM, Cai YP, Gao G (2011) Spatio-temporal heterogeneity of water quality (2010 2011) and succession patterns in Lake Bosten during the past 50 years. J Lake Sci 23, 837-46.

19. Tang X, Xie G, Shao K, Sai-Bayartu Chen Y, Gao G (2012) Influence of salinity on the bacterial community composition in Lake Bosten, a large oligosaline lake in arid northwestern China. Appl Environ Microbiol 78, 4748-51.

20. Guo Y, Zhang RM, Cai LG, Tian YS, Tuerxun TLVT, Lai Y, Ma YW, Xu GQ, et al (2005) Fish Resources and Fisheries in Bosten Lake. Xinjiang Science and Technology Press, Urumchi (in Chinese).
21. Yan XY (1994) Variation and evaluation of zoobentho standing crop in Bosten Lake. Environ Protect Xinjiang 16, 17-20 (in Chinese).

22. Lorenzen CJ (1967) Determination of chlorophyll and pheo-pigments: spectrophotometric equations. Limnol Oceanogr 12, 343-6.

23. Yan QY, Yu YH, Feng WS, Deng WN, Song XH (2007) Genetic diversity of plankton community as depicted by PCR-DGGE fingerprinting and its relation to morphological composition and environmental factors in Lake Donghu. Microb Ecol 54, 290-7.

24. Shannon CE, Weaver G (1949) The Mathematical Theory of Communication. Univ of Illinois Press, Urbana, IL.

25. Steel RGD, Torrk JH, Dickey DA (1997) Principles and Procedures of Statistics: a Biometrical Approach 3rd edn, McGraw-Hill Company Inc., New York.

26. Pielou EC (1969) An Introduction to Mathematical Ecology. John-Wiley, New York.

27. Borcard D, Legendre P, Drapeau P (1992) Partialling out the spatial component of ecological variation. Ecology 73, 1045-55.

28. Yan XY (1991) Zooplankton investigation in Bosten Lake. Arid Environ Monit 5, 177-81 (in Chinese).

29. Wang SB, Xue QJ, Gao G, Tang XM, Chen YG, Gong ZJ (2011) Crustacean zooplankton community structure in Lake Bosten, Xinjiang. J Lake Sci 23, 926-33.

30. Wu L, Feng WS, Chen XJ, Shu FY, Liang XM (2008) Community structure characteristics of zooplankton in Yili region of Xinjiang in summer. Chin J Appl Ecol 18, 163-72.

31. Yuan L, Sun LS, Zhu XJ, Huang SL, Xue JZ, Wu HX (2011) Ecological features of zooplankton community of Hongshan Reservoir in Xinjiang. Arid Land Geogr 34, 1002-8.

32. Yang LL, Zhou XY, Liu QG, Hu ZJ, Wang YB, Jiang M, Shen JZ, Liu ZY, et al (2011) Seasonal succession of crustacean zooplankton in relation to the major environmental factors in Lake Ulungur, Xinjiang. Acta Ecol Sin /Sheng Tai Xue Bao 31, 4468-76 (in Chinese).

33. Greenwald GM, Hurlbert SH (1993) Microcosm analysis of salinity effects on coastal lagoon plankton assemblages. Hydrobiologia 267, 307-35.

34. Halse SA, Shiel RJ, Williams WD (1998) Aquatic invertebrates of Lake Gregory, northwestern Australia, in relation to salinity and ionic composition. Hydrobiologia 381, 15-29.

35. Nielsen DL, Brock MA, Crossle K, Harris K, Healey M, Jarosinski I (2003) The effects of salinity on aquatic plant germination and zooplankton hatching from two wetland sediments. Freshwat Biol 48, 2214-23.

36. Echaniz SA, Vignatti AM, Cabrera GC, José de Paggi SB (2012) Zooplankton richness, abundance and biomass of two hypertrophic shallow lakes with different salinity in central Argentina. Biota Neotropica 12, 41-8. 
37. Malekzadeh Viayeh R, Špoljar M (2012) Structure of rotifer assemblages in shallow waterbodies of semiarid northwest Iran differing in salinity and vegetation cover. Hydrobiologia 686, 73-89.

38. James KR, Cant B, Ryan T (2003) Responses of freshwater biota to rising salinity levels and implications for saline water management: a review. Aust J Bot 51, 703-13.

39. Walsh EJ, Schröder T, Wallace RL, Ríos-Arana JV, Rico-Martínez R (2008) Rotifers from selected inland saline waters in the Chihuahuan Desert of México. Saline Syst 4, 11-9999.

40. Zhao W, He ZH (1999) Biological and ecological features of inland saline waters in North Hebei, China. Int J Salt Lake Res 8, 267-85.

41. Azovsky AI, Mazei YA (2003) Ciliates of coarse ground on the Northeastern Black Sea coast. Zool Zhurnal 82, 899-912.

42. Gehrels WR, Hendon D, Charman DJ (2006) Distribution of testate amoebae in salt marshes along the north American east coast. J Foraminiferal Res 36, 201-14.

43. Zhao W (1992) A review on the Cladocera in inland saline waters. J Dalian Fish Univ 6, 32-41 (in Chinese).

44. Galat DL, Robinson R (1983) Predicted effects of increasing salinity on the crustacean zooplankton community of Pyramid Lake, Nevada. Hydrobiologia 105, 115-31.

45. Peštová D, Macek M, Martínez Pérez ME (2008) Ciliates and their picophytoplankton-feeding activity in a high-altitude warm-monomictic saline lake. Eur $J$ Protistol 44, 13-25.

46. Zhao W, Dong SL, Zhang ZQ, Li DS (2001) Population growth and productivity of the ciliated protozoa community in the enclosures of saline-alkaline ponds. Acta Zool Sin 47, 249-55.

47. Lai Y (2009) Study of season change of phytoplankton in Bosten Lake. J Hydroecol 2, 103-6.

48. Mittelbach GG, Steiner CF, Scheiner SM, Gross KL, Reynolds HL, Waide RB, Willig MR, Dodson SI, Gough L (2001) What is the observed relationship between species richness and productivity? Ecology 82, 2381-96.

49. Dodson SI (1987) Animal assemblages in temporary desert rock pools: aspects of the ecology of Dasyhelea sublettei (Diptera: Ceratopogonidae). J N Am Benthol Soc 6, 65-71.

50. Ganapati SV (1940) The ecology of a temple tank containing a permanent bloom of Microcystis aeraginosa (Kutz) Henfr. J Bombay Nat Hist Soc 17, 65-77.

51. Dodson SI (1992) Predicting crustacean zooplankton species richness. Limnol Oceanogr 37, 848-56. 